\title{
ANALISIS KONTRIBUSI PAJAK DAERAH DAN RETRIBUSI DAERAH TERHADAP PENDAPATAN ASLI DAERAH DI KABUPATEN RAJA AMPAT TAHUN 2010 - 2014
}

\author{
Trivosa Isir ${ }^{1}$ \\ Ventje Ilat ${ }^{2}$ \\ Lidia Mawikere ${ }^{3}$ \\ ${ }^{1,2,3}$ Fakultas Ekonomi dan Bisnis, Jurusan Akuntansi \\ Universitas Sam Ratulangi \\ Email : trivosaisir@yahoo.co.id
}

\begin{abstract}
Local generated revenue is one indicators a successfully on local financials independence in financing governments activiy, because of it regency of King Ampat tried to explore financial resources by local tax and local charges exist to maximize general income. The study aims to determine the extent of the contribution of local taxes and local charges to the local generrated income. The methods used in this research is qualitative diskriptif by explaining the contribusions and the average contribution of each component of local tax and local charge as well as the total contributions of local tax and local charge periode 2010-2014 are presented in table as well as its descriptions. Results from this study indicate that the contribution of local tax and local charge to the local generated income in the regency of King Ampat during the periode of 2010-2014 are fluctuated. The biggest contributios of local tax is occurred in 2014 and the lowest contribution occurred in 2013. While the contribution of the largest in the levies was occurred in 2010 and the lowest contribution occurred in in the year 2013.
\end{abstract}

Keywords :Analysis Contribution, Local Tax, Local Retribution, Local Revenue

\section{Latar Belakang}

\section{PENDAHULUAN}

Sejak diberlakukan otonomi daerah melalui Undang-Undang Nomor 32 Tahun 2004, pemerintah daerah diberikan kewenangan yang luas dengan tujuan untuk mewujudkan kemandirian daerah dalam membiayai dan melaksanakan pembangunannya. Sebagai daerah otonom, daerah mempunyai kewenangan dan tanggung jawab menyelenggarakan pelayanan kepada masyarakat berdasarkan prinsip keterbukaan, partisipasi aktif masyarakat dan wajib melaksanakan pertanggungjawaban kepada masyarakat (Aji : 2014).

Pemberian otonomi yang luas kepada daerah diarahkan untuk mempercepat terwujudnya kesejahteraan masyarakat melalui peningkatan pelayanan, pemberdayaan dan peran serta masyarakat. Di samping itu melalui otonomi luas, daerah diharapkan mampu meningkatkan daya saing dengan memperhatikan prinsip demokrasi, pemerataan, keadilan, keistimewaan dan kekhususan serta potensi dan keanekaragaman daerah dalam sistem Negara Kesatuan Republik Indonesia (Kambu : 2014).

Penyelenggaraan pemerintahan baik melalui administrasi pemerintahan, pembangunan maupun pelayanan kepada masyarakat merupakan salah satu upaya peningkatan stabilitas politik dan kesatuan bangsa. Pemberian otonomi kepada daerah ditujukan supaya daerah mampu bertanggungjawab untuk mengatur dan mengurus rumah tangganya sendiri (Aini : 2015). Sebagai konsekuensi pelaksanaan otonomi daerah, maka masing-masing daerah otonom dituntut untuk berupaya meningkatkan sumber Pendapatan Asli Daerah (PAD) agar mampu membiayai penyelenggaraan pemerintahan dan memberikan pelayanan kepada masyarakat di daerah. Pendapatan Asli Daerah merupakan penerimaan yang dikumpulkan oleh daerah dan merupakan sumber penerimaan utama bagi suatu negara (Jaya \& Dwirandra : 2014).

Beberapa komponen Pendapatan Asli Daerah (PAD) adalah : Pajak Daerah, Retribusi Daerah, Hasil Pengelolaan Kekayaan Daerah yang Dipisahkan, dan Lain-lain PAD yang sah. Empat komponen sumber PAD, khususnya Pajak Daerah dan Retribusi Daerah diharapkan dapat memberikan kontribusi yang positif untuk peningkatan PAD (Kusuma \& Wirawati:2013). Semakin 
besar PAD yang diperoleh oleh kabupaten dan kota untuk membiayai pengeluaran dalam melaksanakan wewenang dan tanggung jawabnya kepada masyarakat, maka akan mengurangi ketergantungan pemerintah daerah terhadap bantuan dari pemerintah pusat (Fery \& Devianty : 2013).

Sama seperti Daerah-Daerah yang lain, Kabupaten Raja Ampat juga merupakan salah satu daerah otonom di era Otonomi Khusus (Otsus) dalam melaksanakan pembangunan, menganut asas desentralisasi yang diwujudkan dalam prakasa baik dalam menentukan kebijakan, perencanaan, pelaksanaan, dan segi pembiayaan maupun perangkat pelaksanaannya (De Rooy : 2015). Kabupaten Raja Ampat masih mengalami kendala dalam menggali potensi-potensi atau sumber daya alam yang ada sebagai penerimaan PAD karena tantangan kondisi geografis dan infrastruktur yang belum memadai, namun guna mempercepat pembangunan dan meningkatkan kesejahteraan masyarakat secara berkelanjutan, pemerintah Kabupaten Raja Ampat berusaha untuk meningkatkan PAD melalui Pajak Daerah dan Retribusi Daerah.

\section{Tujuan Penelitian}

Tujuan dari penelitian ini adalah untuk mengetahui dan menganalisis optimal tidaknya realisasi kontribusi pajak daerah dan retribusi daerah terhadap pendapatan asli daerah di Kabupaten Raja Ampat.

\section{Akuntansi Pemerintahan}

\section{TINJAUAN PUSTAKA}

Menurut Mahmudi (2011:209), menyatakan bahwa sistem akuntansi pemerintahan merupakan serangkaian prosedur manual maupun terkomputerisasi mulai dari pengumpulan data, pencatatan, pengikthisaran, dan pelaporan posisi keuangan dan operasi keuangan organisasi pemerintahan. Akuntansi pemerintah didefinisikan sebagai proses pencatatan, pengumpulan dan pembelanjaan sumber-sumber keuangan pemerintah dan pembuatan laporan keuangan yang terkait dengan beberapa atau semua kegiatan operasional dengan hasilnya. Akuntansi pemerintah merupakan bidang tersendiri yang memerlukan pembahasan yang berbeda dengan akuntansi organisasi lainnya.

\section{Standar Akuntansi Pemerintahan}

Standar Akuntansi Pemerintahan Standar Akuntansi Pemerintahan (SAP) adalah prinsipprinsip akuntansi yang diterapkan dalam menyusun dan menyajikan laporan keuangan pemerintah Pramono, Restianto, dan Bawono (2010:112).

\section{Kinerja}

Kinerja Kinerja organisasi didefinisikan sebagai efektifitas organisasi secara menyeluruh untuk memenuhi kebutuhan yng ditetapkan dari setiap kelompok yang berkenaan melalui usahausaha yang sistematik dan meningkatkan kemampuan organisasi secara terusmenerus untuk mencapai kebutuhannya secara efektif (Sinambela, 2012:186). Dessler (2013: 182) menyatakan bahwa penilaian kinerja adalah merupakan upaya sistematis untuk membandingkan apa yang dicapai seseorang dibandingkan dengan standar yang ada. Tujuannya, yaitu untuk mendorong kinerja seseorang agar bisa berada diatas rata-rata. Dari beberapa pendapat diatas dapat disimpulkan bahwa pengukuran kinerja adalah menilai hasil kerja suatu organisasi publik.

\section{Tujuan Pengukuran Kinerja}

Pengukuran kinerja menurut Sinambela (2012: 187) mempunyai tiga tujuan, yaitu: 1. Membantu memperbaiki kinerja agar kegiatan terfokus pada tujuan dan sasaran program unit kerja. 2 . Pengalokasian sumber daya dan pembuatan keputusan. 3. Mewujudkan pertanggungjawaban publik dan memperbaiki komunikasi kelembagaan.

\section{Aspek - Aspek Pengukuran Kinerja}

Aspek-Aspek Pengukuran Kinerja Sektor Publik Pengukuran kinerja organisasi sektor publik menurut Mohammand (2009:31) meliputi aspek-aspek, antara lain: 1. Kelompok masukan (input); segala sesuatu yang dibutuhkan agar pelaksanaan kegiatan dapat berjalan untuk menghasilkan keluaran. 2. Kelompok proses (process); ukuran kegiatan, baik dari segi kecepatan, ketepatan, maupun tingkat akurasi pelaksanaan kegiatan tersebut. 3. Kelompok keluaran (output); sesuatu yang 
diharapkan langsung dapat dicapai dari suatu kegiatan yang dapat berwujud (tangible) maupun tidak berwujud (intangible). 4. Kelompok hasil (outcome); segala sesuatu yang mencerminkan berfungsinya keluaran kegiatan pada jangka menengah yang mempunyai efek langsung. 5. Kelompok manfaat (benefit); sesuatu yang terkait dengan tujuan akhir dari pelaksanaan kegiatan. 6. Kelompok dampak (impact); pengaruh yang ditimbulkan baik positif maupun negatif.

\section{Pengertian Laporan Keuangan Pemerintah Daerah}

Peraturan Pemerintah Nomor 71 tahun 2010 menjelaskan bahwa laporan keuangan merupakan laporan yang terstruktur mengenai posisi keuangan dan transaksi-transaksi yang dilakukan oleh suatu entitas pelaporan.

\section{Peran Laporan Keuangan}

Menurut Peraturan Pemerintah Nomor 71 Tahun 2010 tentang Standar Akuntansi Pemerintahan, laporan keuangan disusun untuk menyediakan informasi yang relevan mengenai posisi keuangan dan seluruh transaksi yang dilakukan oleh suatu entitas pelaporan selama satu periode pelaporan. Laporan keuangan terutama digunakan untuk mengetahui nilai sumber daya ekonomi yang dimanfaatkan untuk melaksanakan kegiatan operasional pemerintahan, menilai kondisi keuangan, mengevaluasi efektivitas dan efisiensi suatu entitas pelaporan, dan membantu menentukan ketaatannya terhadap peraturan perundang-undangan.

\section{Analisis Rasio Keuangan}

Untuk mengukur kinerja keuangan dalam organisasi pemerintah ada beberapa analisis rasio keuangan yang digunakan, salah satunya sebagai berikut.

Rasio Kemandirian

Rasio Kemandirian $=$ Pendapatan Asli Daerah

Bantuan Pusat dan Pinjaman

Atau

Rasio Kemandirian $=$ Pendapatan Asli Daerah

\section{Pendapatan Asli Daerah}

Total Pendapatan

Berdasarkan Undang-Undang Nomor 33 Tahun 2004, Pendapatan asli daerah selanjutnya disebut PAD adalah pendapatan yang dipungut menurut Peraturan Pemerintah sesuai dengan peraturan perundang-undangan". Selanjutnya, yang dimaksud dengan Pendapatan Asli Daerah berdasarkan UU No.34 Tahun 2004 adalah Pendapatan daerah yang bersumber dari hasil Pajak Daerah, hasil Retribusi Daerah, hasil pengelolaan kekayaan daerah yang dipisahakan, dan lain-lain Pendapatan Asli Daerah yang sah, yang bertujuan untuk memberi keleluasaan kepada daerah dalam menggali pendanaan dalam pelaksanaan otonomi daerah sebagai perwujudan asas desentralisasi.

\section{Pajak Daerah}

Pajak daerah merupakan sumber keuangan pokok di samping retribusi daerah. pajak daerah adalah iuran wajib yang dilakukan oleh daerah kepada orang pribadi atau badan tanpa imbalan langsung yang seimbang, yang dipaksakan berdasarkan peraturan perundang-undangan yang berlaku, yang digunakan untuk membiayai penyelenggaraan pemerintah daerah dan pembangunan daerah. dengan demikian, pajak daerah merupakan pajak yang ditetapkan oleh pemerintah daerah peraturan daerah (Perda) yang wewenang pemungutannya dilakukan oleh pemerintah daerah dan hasilnya digunakan untuk membiayai pengeluaran pemerintah daerah dalam melaksanakan penyelenggaraan pemerintah dan pembangunan di daerah (Siahaan, 2010:9). 


\section{Retribusi Daerah}

Sebagaimana halnya pajak daerah, retribusi daerah diharapkan menjadi salah satu sumber pembiayaan penyelenggaraan pemerintahan dan pembangunan daerah, untuk meningkatkan dan memeratakan kesejahteraan masyarakat. Siahaan (2010:5,6) menyatakan bahwa Retribusi adalah pembayaran wajib dari penduduk kepada negara karena adanya jasa tertentu yang diberikan oleh negara bagi penduduknya secara perorangan. Jasa tesebut dapat dikatakan bersifat langsung, yaitu hanya yang membayar retribusi yang menikmati balas jasa dari negara.

\section{Kontribusi}

Kontribusi adalah besaran sumbangan yang diberikan atas sebuah kegiatan yang dilaksanakan (Handoko, 2015:34). Kontribusi juga merupakan sesuatu yang dilakukan untuk membantu menghasilkan atau mencapai sesuatu bersama-sama dengan orang lain, atau untuk membantu membuat sesuatu yang sukses.

Contohnya seperti ketika kita memberikan kontribusi, itu berarti kita memberikan sesuatu yang bernilai bagi sesama, seperti uang, harta benda, kerja keras ataupun waktu kita.

\section{Penelitian Terdahulu}

Erwan Cahya Setiyono (2014) dengan judul Analsisis Kontribusi Pajak Daerah Dan Retribusi Daerah Terhadap Pendapatan Asli Daerah Kabupaten Purworejo, tujuannya untuk mengetahui berapa besar tingkat kontribusi pajak daerah dan retribusi daerah terhadap PAD Kabupaten Purworejo, metode penelitian yang digunakan adalah metode deskriptif. Hasil dari penelitian ini dapat diketahui rata-rata pajak daerah terhadap PAD periode 2010-2014 adalah sebesar 15,74\%, sedangkan rata-rata kontribusi retribusi daerah terhadap PAD periode 2010-2014 sebesar 13,89\%. Jadi kontribusi pajak dan retribusi daerah secara keseluruhan sudah memberikan kontribusi yang baik terhadap pendapatan Kabupaten Purworejo. Terdapat persamaan dan perbedaan dengan penelitian yang dilakukan. Persamaanya yaitu penelitian deskriptif, perbedaannya pada objek penelitian.

\section{Jenis Penelitian}

\section{METODE PENELITIAN}

Jenis penelitian yang digunakan berupa jenis penelitian deskriptif, Sugiyono (2010:29) menjelaskan bahwa penelitian deskriptif adalah metode yang digunakan untuk menggambarkan atau menganalisis suatu hasil penelitian tetapi tidak digunakan untuk membuat kesimpulan yang lebih luas.

\section{Tempat dan Waktu Penelitian}

Lokasi tempat penelitian adalah pada Dinas Pendapatan Daerah Kabupaten Raja Ampat Papua Barat. Adapun waktu penelitian ini mulai dilakukan 6 bulan mulai dari bulan Desember s/d Mei 2016 yang meliputi kegiatan pengumpulan data dan literatur, pengolahan data, analisis data, hingga penulisan laporan dalam bentuk skripsi.

\section{Prosedur Penelitan}
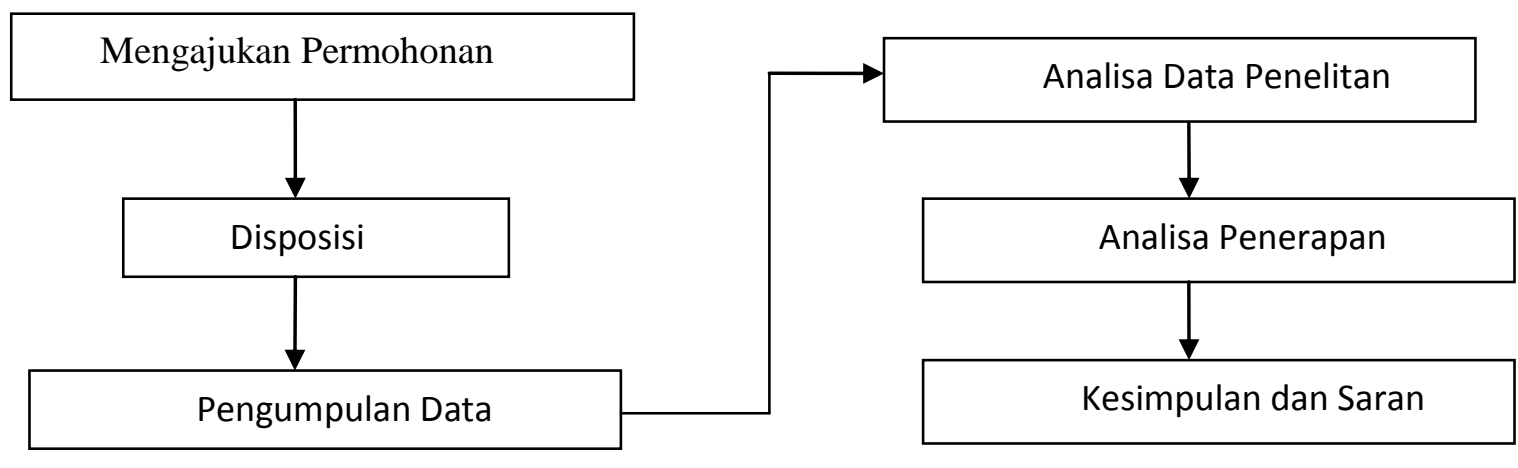

Sumber : prosedur penelitian pribadi 


\section{Objek Penelitian}

Objek penelitian ini dilakukan pada Dinas Pendapatan Daerah Kabupaten Raja Ampat yang beralamat di Kantor Bupati dan letaknya cukup strategi karena berada dipusat Kabupaten sehingga mudah dijangkau, Kabupaten Raja Ampat merupakan sebuah kabupaten di Provinsi Papua Barat yang dimekarkan dari Kota Sorong pada tahun 2003.

\section{Sumber Data}

Sugiyono $(2010 ; 16)$ menyatakan bahwa pengumpulan data dapat menggunakkan dua sumber yaitu sumber primer dan sumber sekunder sebagai berikut.

1. Data Primer yaitu data yang diperoleh dari aparatur pemerintahan dibagian PAD Dinas Pengelola Keuangan Kabupaten Raja Ampat.

2. Data Sekunder yaitu data yang diperoleh dari Buku, Jurnal Nasional, dan Jurnal Internasional.

\section{Teknik Pengumpulan Data}

Dalam memperoleh data yang berhubungan dangan penelitian ini, penulis menggunakkan pengumpulan data dengan metode Wawancara, yaitu dilakukan tanya jawab dan diskusi secara langsung dengan bagian Badan Pengelola Keuangan dan Aset Daerah Kabupaten Raja Ampat.

\section{Metode Analisis}

Metode analisis yang digunakan untuk membahas permasalahan dalam penelitian ini adalah analisis deskriptif kuantitatif. Metode analisis ini digunakan analisis kontribusi dan untuk mengukur kinerja keuangan dengan rasio keuangan yaitu rasio kemandirian.

\section{HASIL PENELITIAN DAN PEMBAHASAN}

\section{Tabel 1}

Target dan Realisasi PAD Kabupaten Raja Ampat Tahun 2010-2014

\begin{tabular}{ccccc}
\hline No & Tahun & Target PAD & Realisasi & \% \\
\hline 1 & 2010 & $708.010 .000,00$ & $324.623 .050,00$ & 79,59 \\
2 & 2011 & $2.686 .237 .000,00$ & $266.885 .750,00$ & 99,36 \\
3 & 2012 & $3.252 .541 .000,00$ & $662.726 .000,00$ & 20,44 \\
4 & 2013 & $827.000 .000,00$ & $1.092 .495 .310,00$ & 205 \\
5 & 2014 & $890.345 .280,00$ & $1.887 .996 .342,00$ & 224 \\
\hline
\end{tabular}

Sumber : Dinas Pendapatan Daerah Kabupaten Raja Ampat

Berdasarkan Tabel diatas dapat diketahui Pendapatan Asli Daerah (PAD) Kabupaten Raja Ampat tahun 2010 mencapai Rp. 407.927.000,00 dengan realisasi sebesar Rp. 324.623.050,00 atau sebesar 79,59\%. Tahun 2011 target PAD mengalami peningkatan menjadi Rp. 2.686.237.000,00 dengan realisasi Rp. 266.885.750,00 atau sebesar 99,36\%, kemudian pada tahun 2012 target PAD meningkat menjadi 3.252.54.000 dengan realisasi Rp. 662.726.000 atau sebesar 20,44\%. Pada tahun 2013 PAD Kabupaten Raja Ampat mengalami penurunan menjadi Rp. 827.000.000,00 dengan realisasi mengalami peningkatan sebesar Rp. 1.092.495.310,00 atau sebesar 205\%, dan pada tahun 2014 taget PAD meningkat menjadi Rp. 980.345.280,00 dengan realisasi sebesar Rp. 1.887.996.342,00 atau sebesar 224\%. 
Tabel 2

Kontribusi Pajak Daerah dan Retribusi Daerah terhadap Pendapatan Asli Daerah (PAD)

Kabupaten Raja Ampat Tahun 2010-2014

\begin{tabular}{lcccccc}
\hline Tahun & $\begin{array}{c}\text { Pajak Daerah } \\
(\text { Rp) }\end{array}$ & $\begin{array}{c}\text { Retribusi Daerah } \\
(\text { RP) }\end{array}$ & $\begin{array}{c}\text { PAD } \\
\text { (Rp) }\end{array}$ & $\begin{array}{c}\text { Kontribusi } \\
\text { Pajak } \\
\text { Daerah } \\
\text { terhadap } \\
\text { PAD }\end{array}$ & $\begin{array}{c}\text { Kontribusi } \\
\text { Retribusi } \\
\text { Daerah } \\
\text { terhadap } \\
\text { PAD }\end{array}$ & $\begin{array}{c}\text { Kontirbusi } \\
\text { PD + RD } \\
\text { terhadap } \\
\text { PAD }\end{array}$ \\
\hline 2010 & 36.297 .800 & 288.325 .250 & 324.623 .050 & $11,18 \%$ & $89 \%$ & $100,18 \%$ \\
2011 & 26.239 .000 & 214.288 .750 & 266.885 .750 & $10 \%$ & $80,30 \%$ & $90,3 \%$ \\
2012 & 78.310 .000 & 584.416 .000 & 662.726 .000 & $12 \%$ & $88,19 \%$ & $100,20 \%$ \\
2013 & 342.933 .310 & 784.092 .000 & 1.092 .495310 & $31,40 \%$ & $72 \%$ & $103,4 \%$ \\
2014 & 1.230 .234 .342 & 657.762 .000 & 1.887 .996 .342 & $65,16 \%$ & $35 \%$ & $100,16 \%$ \\
& & & & $30,00 \%$ & $75,15 \%$ & $100 \%$ \\
\hline
\end{tabular}

Sumber : Dinas Pendapatan Daerah Kabupaten Raja Ampat

Berdasarkan hasil perhitungan pada tabel 4.8, dapat diketahui untuk tahun 2010 pajak daerah memberikan kontribusi sebesar 11,18\% terhadap PAD. Pada tahun 2011 kontribusi pajak daerah mengalami penurunan sebesar 10\% terhadap PAD. Tahun 2012 kontribusi pajak daerah sebesar 12\%, kemudian pada tahun 2013 dan 2014 kontribusi pajak daerah terhadap PAD mengalami peningkatan yaitu sebesar $31,40 \%$ dan $65,16 \%$.

Kontribusi retribusi terhadap PAD selama 6 tahun adalah sebagai berikut. Untuk tahun 2010 adalah sebesar 89\%, untuk tahun 2011 sebesar 80,30\%. Kemudian pada tahun 2012, 2013 dan 2014 kontribusi retribusi terhadap PAD mengalami peningkatan yaitu sebesar 72\%, 35\% dan $100 \%$.

Tabel 3

Hasil Analisis Rasio Kemandirian Keuangan Daerah

\begin{tabular}{ccc}
\hline Tahun & $\begin{array}{c}\text { Rasio Kemandirian keuangan } \\
\text { daerah }\end{array}$ & Pertumbuhan \\
\hline 2010 & $0,84 \%$ & Baik \\
2011 & $0,11 \%$ & Kurang Baik \\
2012 & $0,029 \%$ & Baik \\
2013 & $0,24 \%$ & Kurang Baik \\
2014 & $0,52 \%$ & Baik \\
\hline
\end{tabular}

Sumber : Data Diolah Penulis

Berdasakan hasil penelitian dengan mengggunakan analisis rasio kemandirian keuangan daerah menunjukkan bahwa pada tahun 2010 mengalami peningkatan sebesar 0,84\% kemudian pada tahun 2010 mengalami penurunan sebesar $0,11 \%$. Pada tahun 2012 kembali mengalami peningkatan yaitu sebesar $0,29 \%$, pada tahun 2013 mengalami penurunan sebesar 0,24\% dan pada tahun terakhir yaitu 2014 kembali meningkat sebesar 0,52\%.

Kesimpulan penelitian ini adalah :

\section{PENUTUP}

1. Berdasarkan hasil analisis kontribusi dapat diketahui bahwa selama tahun pengamatan 2010-2014, realisasi terbesar pajak daerah terhadap PAD terjadi pada tahun 2014 yaitu Rp 1.887.996.342,00 dari target Rp 1.234.234.342,00 atau sebesar 65,16\% dan tahun 2013 yaitu Rp 1.092.495.310,00 dari target Rp 342.933.310,00 atau sebesar 31,40\%.

2. Hasil analisis kontribusi dapat diketahui bahwa selama tahun pengamatan 2010-2014, realisasi terbesar retribusi daerah terhadap PAD terjadi pada tahun 2014 yaitu Rp 1.887.996.342,00 dari target Rp 657.762.000,00 atau sebesar 35\% dan tahun 2013 yaitu Rp 342.933.310 dari target Rp 784.092.000,00 atau sebesar 72\%. 
3. Hasil analisis menunjukkan bahwa pajak daerah dan retribusi daerah adalah dua sumber utama pendapatan asli daerah bagi Kabupaten Raja Ampat dan memberikan kontribusi yang besar.

4. Berdasarkan rasio kemandirian keuangan daerah, kinerja keuangan Pemerintah Kabupeten Raja Ampat mengalami peningkatan atau dinilai baik terjadi pada tahun 2010, 2012, 2014 dengan presentase pertumbuhan 0,84\%, 0,29\%, 0,52\%. Kemudian pada tahun 2011 dan 2013 mengalami penurunan atau dinilai kurang baik dengan presentase pertumbuhan hanya mencapai $0,11 \%, 0,24 \%$.

\section{Saran}

1. Pemerintah Daerah Kabupaten perlu menggunakkan teknik analisa data yang digunakan dalam penelitian yaitu Analisis Persentase Kontribusi supaya dapat meningkatkan Kontribusi Pajak dan Retribusi terhadap Pendapatan Asli Daerah (PAD) untuk menggali potensi-potensi daerah sebagai sumber dalam PAD lebih khusus Penerimaan Pajak Daerah dan Retribusi Daerah, agar dapat memberikan kontribusi yang besar bagi daerah tersebut.

2. Pemerintah Daerah Kabupaten perlu menyediakan berbagai fasilitas yang dapat menunjang peningkatan PAD sesuai dengan kebutuhan dan keadaan daerah tersebut.

3. Masyarakat perlu diberikan sosialisasi dan pandangan tentang pentingnya kesadaran dan tanggung jawab masyarakat dalam pembayaran pajak. Karena dalam hal ini masyarakat merupakan subjek pajak yang adalah penunjang tercapainya realiasasi penerimaan PAD sesuai target.

\section{Daftar Pustaka}

Ditya Nanaryo Aji, 2014. “Analisis Dampak Objek Wisata Gua Pindul Terhadap Peningkatan Pendapatan Masyarakat Desa Bejiharjo” Jurnal Ilmiah Mahasiswa FEB Universitas Gadjah Mada Yogyakarta.

Freddy De Rooy, 2015. “Analisis Kontribusi Penerimaan Pajak Daerah Terhadap Pendapatan Asli Daerah (Pad) Di Kabupaten Raja Ampat” Jurnal EMBA, Vol 3 (4) 451-461.

I Putu Ngurah Panji Kartika Jaya, A.A.N.B. Dwirandra, 2014. "Pengaruh Pendapatan Asli Daerah Pada Belanja Modal Dengan Pertumbuhan Ekonomi Sebagai Variabel Pemoderasi” Jurnal Ilmiah Mahasiswa FEB Universitas Udayana Bali, Vol 7 (1).

Irlan Fery, Zely Devianty, 2013. “Analisis Kontribusi Pajak Daerah Terhadap Pendapatan Asli Daerah Di Kabupaten Musi Banyuasin” Jurnal Ekonomi dan Informasi Akuntansi (Jenius) STIE Rahmaniah Sekayu, Vol 3 (2).

Krisna Arta Anggar Kusuma, Ni Gst. Putu Wiarawati, 2013. “Analisis Pengaruh Penerimaan Pajak Daerah Dan Retribusi Daerah Terhadap Peningkatan PAD Sekabupaten/Kota Di Provinsi Bali”, Jurnal Ilmiah Mahasiswa FEB Universitas Udayana Bali.

Mahmudi, 2010. Analisis Laporan Keuangan Pemerintah Daerah. Edisi Kedua. Penerbit UPP STIM YKPN. Yogyakarta .

Mohammand Mahsun, 2009. Pengukuran Kinerja Sektor Publik.Edisi pertama, BPFE. Yogyakarta.

Pramono Hariadi, Tanuar E. Restianto dan Icuk R. Bawono, 2010. Pengelolaan Keuangan Daerah. Penerbit: Salemba Empat. Jakarta.

Susi Susanti Kambu, Debby Ch. Rotinsulu, Steva Y.L. Tumangkeng, 2014. "Kontribusi Pajak Dan Retribusi Daerah Terhadap Pendapatan Asli Daerah Kabupaten Sorong” Jurnal EMBA.

Sinambela, Lijan Poltak. 2012. Kinerja Pegawai: Teori Pengukuran dan Implikasi. Yogyakarta:Grahailmu 